\title{
Investment strategies in pandemic situations: an analysis and comparison of prospective returns between developed and emerging markets
}

\author{
Konstantin B. Kostin \\ Saint-Petersburg State University of Economics, St. Petersburg, Russia \\ Philippe Runge \\ Nordakademie Graduate School, Hamburg, Germany
}

Ronald Adams

University of North Florida, Jacksonville, USA

\begin{abstract}
This study empirically analyzes return data from developed and emerging markets to assess whether emerging markets show superior performance during the COVID-19 pandemic in terms of cost of equity. It analyses panel data from eight country indices of developed and emerging countries as well as eight exemplary companies from developed and emerging countries, covering the period from 2000 to 2020 . The results provide evidence that emerging markets do not perform in a better way than developed markets. The findings highlight the need for a reassessment of the generalized notion that emerging markets are more profitable than developed markets in such crises which affect the core of their economic structure. It provides investors with meaningful advice on the creation of an investment strategy if they wish to perform equity investments in similar periods like the COVID-19 pandemic. The study contributes to the literature by advancing this research area and is the first study which analyzes and compares the cost of equity of developed and emerging markets during the COVID-19 pandemic.
\end{abstract}

\section{Keywords}

COVID-19; pandemic; asset pricing; Fama French three factor model; cost of equity investment; behavioural finance; developed; emerging; panel data.

\section{Introduction}

In the past decades, the global economy was affected by numerous financial crises with detrimental economic, sociocultural, and political ramifications. The emergence of such situations is a rather continuous phenomenon and crises have been occurring regularly for at least the last century. Many of said crises often only affected single countries with some bordering nations, like the 1998 Russian Financial Crisis or the Icelandic Financial Crisis of 2008 to 2010 . However, some of these events were of such magnitude due to their underlying causes that they affected the economies of many nations around the globe, regardless of the region. Such crises included the dot-com bubble in 2001, the Great Recession between 2007 and 2010 as a result from the Global Financial Crisis (GFC) of 2007 to 2008 or the ongoing European debt crisis from 2009. It is particularly interesting that these global crises are somewhat similar in their nature. Although the actual causes for their occurrence may differ, these types of financial crises only spread to the rest of the world after a certain time delay. For example, the recent recession, which began with the United States' housing bubble between 2005 and 2006, which then led to the US subprime 
mortgage crisis and further developed into a global recession over a course of several years. The biggest threat to the global economic system of today in contrast to the former developments is the COVID-19 pandemic (Drobot, Makarov, Nazarenko \& Manasyan, 2020). The term COVID-19 describes an infectious virus disease in humans that is caused by the so-called SARS$\mathrm{CoV}-2$ virus strain. While this virus is remarkably similar to the yearly influenza in terms of its range of symptoms, it is considered a significant threat to health systems and economies throughout the globe for the following reasons:

- It is a novel virus with no known cure or preventive vaccination.

- It is an airborne disease, able to spread meters around an infected individual.

- It can spread much more rapidly between humans than other known respiratory diseases. Sanche, Romero-Severson, Hengartner and $\mathrm{Ke}$ (2020) indicate in a recent study that this disease shows an R0 of 5.7. This number indicates that one infected person, on average, has the ability to infect five to six people with this virus. This number puts this virus's risk of spreading to a large number of individuals on one level with dangerous diseases such as Poliomyelitis, Smallpox, or Pertussis.

- Albeit its name, SARS-Cov-2 aggressively infects more organs than just the respiratory tract; e.g. it is also able to cause substantial damage to the human heart, the gastrointestinal tract, the nervous system, and triggers massive immune responses, making it difficult to control and treat infected patients.

Unlike other financial crises, Covid successfully attacks the very nature of thriving economic structures: human interaction and stable population health levels. Consequently, this pandemic showed its full effect on practically all areas of economic undertakings. As people are prohibited from leaving their homes for work, most types of shopping, and practically all forms of recreational activities for several months so far, entire industry sectors experienced massive plunges of revenue and profits on a global scale. This caused rising unemployment rates and had negative effects on the economic growth figures of both developed and undeveloped countries. Additionally, certain industrial sectors have been affected much more significantly by this pandemic than others, mostly due to the underlying nature of their business operations. Those sectors that require an extensive degree of human interaction, such as the aviation or tourism industry, appear to be affected to a larger degree than digital businesses, which require practically no face-to-face client-employee interaction at all. Surprisingly, at a first glance, it appears as if developing countries, especially those nations belonging to the emerging market classification, have been hit less severely - economically speaking - by this pandemic than those countries that are considered developed economies.

According to O'Sullivan and Sheffrin (2003), a developed country is a sovereign state that has a developed economy and advanced technological infrastructure relative to other less industrialized nations. A developing country is a country with a less developed industrial base and a low Human Development Index relative to other countries. Emerging markets, also known as emerging economies or developing countries, are nations that are investing in more productive capacity (Amadeo, 2020; Vertakova \& Plotnikov, 2013).

Therefore, this study aims to research the following hypothesis:

In times of the COVID-19 pandemic, emerging markets express investment potential at better cost of equity levels than developed markets.

As no research is available on specific investment options in global pandemics, simply for the fact that comparable pandemics have not occurred in the modern age yet, this paper aims to fill this gap and add to the understanding of the financial impact of global pandemics and to provide meaningful data to investors who are looking for investment advice in such situations.

\section{Literature review}

Morgan Stanley Capital International (MSCI, 2014) lists specific criteria to assess whether a country may be considered developing (emerging) or developed. It must be noted that MSCI classifies developing markets as frontier markets; a category that only includes countries with higher development standards than the least developed countries (LDC). Consequently, MSCI does not include the complete variety of developing countries, but only those that meet a certain minimum standard of factors to be compared against developed nations. MSCI (2014) explains that three criteria are being assessed to determine the status of a market accordingly: 
- Economic Development (precisely sustainability of economic development over a certain period of time)

- Size and Liquidity Requirements

- Market Accessibility Criteria

Based on the outlined criteria, MSCI (2014) explains that emerging markets must have at least three companies operating in its market with a market capitalization of more than roughly 1.2 billion US dollars, a security size of 630 million dollars and at least a $15 \%$ annualized traded value ratio (ATVR) as measure of security liquidity. Additionally, and rather important for this study, MSCI (2014) explains that emerging markets must express significant openness to foreign ownership and ease of capital in- and outflow as well as sufficiently tested operational frameworks and acceptable levels of institutional frameworks. In contrast, frontier markets only need to show reduced levels of openness to foreign ownership and ease of capital in- and outflow (Subic, Vasiljevic, \& Andrei, 2010). Consequently, nations belonging to the frontier market classification will not be considered for this study as their business circumstances are highly volatile and unreliable for investors who are looking for meaningful and trustworthy investment options in situations with a considerable amount of uncertainty such as global pandemics. It would be foolish in such fickle situations to suggest investments into regions and markets that already express a substantial risk of suffering extensive losses in normal times. When speaking about emerging markets, Griffin, Kelly, and Nardari (2010) state that it is a common perception that investments in these markets are more profitable than in developed markets. As a supporting argument, Waszczuk (2013) states that higher average returns from these markets are achieved because of the significantly higher risk in relation to political instability, forms of government, level of corporate governance, as well as geographical location.

However, Griffin et al. (2010) suggest in their study that this point does not hold true. Griffin et al. (2010) mention that, for example, an application of short-term reversal strategies yielded roughly 9 percent of annual profits in developed markets, while developing markets produced approximately 11 percent of profits. Both results are quite close to each other and suggest a certain lack of strong superiority of emerging markets over developing markets in normal economic circumstances with higher risk levels in emerging markets. Griffin et al. (2010) also add further evidence to this notion in the strategy of exploitation of incomplete incorporation of earnings news into new stock prices. According to Griffin et al. (2010), emerging countries show even weaker profit production here with only 8.5 percent of annual profit, compared to a 14 percent profit yield in developed countries. Altogether, the results of this study are discouraging to the perception of excessively higher profit potential in emerging markets. Surprisingly, Didier, Hevia, and Schmukler (2011) hold against these findings that emerging markets outperformed developing markets during the Global Financial Crisis of 2007 to 2008 in terms of the number of months spent under recessionary pressure. Didier et al. (2011) show that emerging countries - grouped as a whole - were able to reach their pre-crisis levels of production in September 2009 already, only approximately one year after the full effects of the crisis have unfolded, while developing countries were still below their pre-crisis production levels by the end of 2010. Didier et al. (2011) mention four factors that have contributed to this significantly better growth performance:

- Emerging countries were less connected to financial markets of developed countries in which the root cause of the Global Financial Crisis occurred.

- Emerging countries focus more on production of goods than provision of services. As global demand for products increased again after the crisis and after the crisis has not transmitted fully into emerging markets, the emerging markets were able to recover faster than developed countries where manufacturing usually accounts for smaller shares of their economy.

- Emerging countries generally show higher growth rates than developed countries. Returning to their initial growth trajectories in a post-crisis setting allows them to overtake developed countries in terms of recovery.

- Emerging countries have applied fundamental changes to their policy framework, both to more reasonable financial and macroeconomic policies that allowed them to tackle crises more efficiently.

Although the findings from Griffin et al. (2010) suggest that emerging markets may not 
fare well in terms of their proposed investment strategies, it could be the case that emerging markets may be more resilient to economic turmoil and are able to recover faster than developed markets. However, despite the empirical evidence that emerging markets and the available companies in these markets may effectively not prove more profitable than developed countries, these markets have never seen a crisis of the nature of the COVID-19 pandemic. Consequently, it may be possible that profitability differences exist between emerging markets and developed markets due to an improved pace of crisis recovery and stronger economic growth rates which have not been discovered yet. Investments into emerging markets may potentially prove to be fruitful in immediate post-crisis situations where emerging markets may display superior performance in terms of resumption of economic activity and achieving pre-pandemic production and revenue levels.

\subsection{Choosing the right asset pricing model}

\subsubsection{Capital Asset Pricing Model (CAPM)}

When one thinks about determining asset pricing models to pursue research on the cost of equity of assets, the most prominent answer to that question will be CAPM. William Sharpe (1964), John Lintner (1965), and Jan Mossin (1966) developed CAPM independently around the same time. It is fundamentally based on one factor that is the relationship between market beta and expected return of an underlying asset. Simply speaking, CAPM assumes one plain idea: the higher the risk or beta, the higher the returns of a specific asset. Jensen, Black, and Scholes (1972) confirmed in their study that this model is apparently effective and is able yield meaningful results after it has been tested on data of all securities listed on the NYSE between 1926-1966. At a first glance, CAPM would therefore be a more or less acceptable model for the relevant asset pricing. However, the model itself has both been proven to be inherently insufficient in providing precise return estimations and to be based on confining assumptions that are unrealistic in a real world setting. Additionally, as Banz (1981) mentioned, CAPM appeared to be misguided, as it was not effective during the analysis of securities that were sorted according to their market capitalization. Fama and French (2004) even go so far as to state that the available empirical evidence is sufficient to invalidate practically all applications of CAPM, as the model cannot truly be tested. They add that one of the model's major flaws is the reliance on the market portfolio as the heart of the model. Fama and French (2004) state that the market portfolio is a highly elusive concept, both theoretically and empirically. Consequently, they argue that any test of CAPM must employ proxies for the market portfolio, as it is impossible to determine the market portfolio effectively at any point in time. Roll (1977) already extended on this downfall shortly after CAPM has been introduced, stating that the use of proxies completely invalidates CAPM. Roll (1977) explains in detail that only one testable hypothesis is associated with CAPM, which is that the market portfolio is mean-variance efficient and that further implications from this model cannot be independently tested. Roll (1977) highlights in that regard that all other implications of the model directly follow from the market portfolio's efficiency and cannot be verified on an individual basis as the linear relationship of beta and returns are inextricably connected to the market portfolio mean-variance efficiency. Roll (1977) directly criticizes that CAPM cannot be tested in any way unless the full composition of the market portfolio is known and used for testing, meaning that CAPM can truly not be tested unless every single tradeable asset in existence is included in the sample of observations. Additionally, Roll (1977) explains that the used proxies may also be mean-variance efficient, which would result in samples that display efficient portfolios with the ability to perfectly satisfy all of CAPM's underlying assumptions or the proxies may turn out to be inefficient. However, this would not yield any meaningful statement about the efficiency of the true market portfolio. As a response to these insurmountable obstacles, Fama and French (2004) add that proxies for the true market portfolio will never be able to produce betas and market premiums that can explain the return on any given portfolio. Consequently, these proxies cannot be considered trustworthy approximations of the true market portfolio. One may ask in that case why CAPM is still widely being used. The answer is rather easy: The model is simple. It assumes an easy-tounderstand linear relationship between market beta and return. A survey conducted by Graham and Harvey (2001) supports these perceptions, in which $73.5 \%$ of the surveyed CFOs from companies in the US stated that they always or 
practically always use CAPM for the calculation of the cost of equity capital. However, it has been shown in numerous tests that the model's assumption is not sufficient to accurately describe potential returns for the underlying asset and that various anomalies exist which cannot be explained when using CAPM. While it may allow for an initial and simple estimation of potential returns, its results must be treated with caution, as they do not capture a large amount of the variety within underlying assets. Consequently, CAPM will not be used for the analysis of asset data in this study, as its results are significantly inferior to those of other, more advanced asset pricing models.

\subsubsection{Fama French Three-Factor Model}

In the beginning of the 90 s of the 20th century, CAPM had extensively been researched and criticized; to such a point that most researchers deemed this model invalid in the striking majority of its stipulated fields of application. Consequently, researches looked for more comprehensive asset pricing models that showed an improved ability to explain the variations of the underlying assets. Fama and French introduced such a model in 1993, calling it the three-factor model. As Arnold and Lewis (2019) explain, Fama and French managed to demonstrate superiority of smaller companies in that they produced higher returns than larger companies did. Additionally, Arnold and Lewis (2019) outline that Fama and French were able to prove that such companies that held considerably high net assets compared to the share market value of the company performed significantly better compared to those companies with fewer net assets as proportions of the company's share market value. Fama and French (1993) used the CAPM as a fundamental basis for their new model but expanded it with factors capturing the company return findings. The newly added factors were labelled size and value factor or small [market capitalization] minus bug (SMB) and high [book-to-market ratio] minus low (HML). As Arnold and Lewis (2019) stipulate, the model attempts to capture those systematic risk factors not captured by the initial CAPM. Fama and French (1996) tested their model on shares exclusively in the US - and concluded that the model is highly effective for return calculation of portfolios that are formed on size and book-tomarket equity. In another study, Fama and French (1998) extended their widely US-specific test of the model to a global version, splitting all factors into a domestic and a foreign part, and reported a considerably good performance of the model on an international scale. In contrast, Moerman (2005) suggested in a study conducted on data from the European Union that the global version of the three-factor model showed signs of underperformance compared to more local, country-specific versions. Nevertheless, all available empirical results for this model hold one commonality: they significantly surpass the outdated CAPM in terms of explanations of the returns from diversified portfolios. Belyh (2019) states that the three-factor model is able to explain at least $90 \%$ of these returns, while CAPM is only able to provide explanations for approximately $70 \%$ of these returns. Consequently, the threefactor model has received widespread acclaim by researchers and continued to be a praised asset pricing model until today. Naturally, however, it has received criticism and suggestions for improvement over the years after numerous empirical studies have been conducted on its applicability. One practical issue - if it can be called an issue at all - is the fact that this model is considerably more complex than CAPM. While CAPM relies on relatively simple data sources for beta, the three-factor model includes factors that require a much greater extent of computation and time spent on the identification and processing of data sources. Additionally, one of the model's strongest downsides is its fundamental CAPM connection. As mentioned above, this model has been an innovative extension of the CAPM formula with the clear goal to be able to explain a higher percentage of the portfolio return variations. In that case, however, it does not really supersede CAPM. It merely expands the CAPM formula in such a way that the lack of explanatory power is addressed, but not the underlying and problematic assumptions of CAPM. In order to avoid redundancy, more detailed criticism on this model will be provided in the next chapter on the Fama French five-factor Model as the five-factor model is only an extended version of the threefactor model and is thereby based on CAPM as well. Consequently, both models bear the same underlying issues.

\subsubsection{Fama French five-factor model}

As a direct extension to the Fama French threefactor model, Fama and French introduced a new asset pricing model in 2015. As Arnold and Lewis (2019) state, Fama and French were able to 
demonstrate that such companies offer higher returns on their shares that have higher profits-tonet-asset ratios and add that this observation was not captured by the three-factor model. Additionally, Fama and French $(2015 \mathrm{a}$, cited in Arnold and Lewis, 2019) analysed that companies which showed small changes in total assets over the last year performed much better than such companies which showed large increases in their investment levels. Consequently, Fama and French (2015) have added factors to the threefactor model that are believed to capture these discoveries accurately. Those have been the Profitability and Investment factors, or robustminus-weak [profitability] (RMW) and conservative-minus-aggressive [investment] (CMA) (Fama \& French, 2015b). This is a particularly special development as these factors are quality-based and not risk-related as the other factors from the three-factor model. It is a direct response to the fact that a plethora of studies on the three-factor model reported alpha values significantly different from zero. Therefore, it led to the conclusion that the three-factor model is not sufficiently comprehensive and that further factors are required to describe the cross section of portfolio returns. In their follow-up paper, Fama and French (2015a) stated that the five-factor model addresses practically all issues from the three-factor model, thereby proving to be far superior to the initial three-factor approach. However, despite its advantages in a more comprehensive asset pricing and being considered a decisive extension to the three-factor model, the Fama French (2015a) five-factor model contains major flaws as well which make a wide-ranging application of the model questionable now. Surprisingly, the available literature containing direct criticism of this model on a general scale is rather scarce. The majority of published papers deal with empirical testing of the applicability of this model to certain markets and raise potential issues with the use of the model in the researched fields, e.g. emerging markets or certain industrial sectors, but only a vanishingly small amount of papers dared to offer direct criticism of the model itself and its underlying assumptions. Blitz, Hanauer, Vidojevic, and Vliet, (2018) have engaged themselves in thorough criticism of the five-factor model and its underlying assumptions. Blitz et al (2018) have outlined major concerns of this model of which the following are most relevant for this study:
- The model retains the CAPM's relation between market beta and return, resulting in the negligence of a low-volatility premium.

- Momentum is still not considered as a factor in the model.

- The economic rationale for the model is unclear.

It is not surprising to see that the Fama French five-factor model also does not account for the prominently discussed low-beta premium as the heart of this model is still the CAPM. Just like with Fama and French's (2015a) three-factor model, the underlying core assumption is the linear relationship between higher market beta values and a subsequent increase of returns for the underlying asset. Fama and French (2015a) justify their CAPM basis by stating that the addition of CAPM by RMW and CMA, given a positive exposure to these factors, are remarkably successful in capturing the average returns of lowvolatility stocks. However, these results have been challenged as being premature. Blitz and Vidojevic (2017) determined that exposure to beta in the cross-section of stocks is not directly rewarded with drastically higher returns as one would expect. In contrast, Blitz and Vidojevic (2017) ascertain that testing the five-factor model for low-risk anomalies results in a flat relationship between risk and return, instead of a largely positive relationship as previously claimed by Fama and French (2015a). Consequently, Blitz and Vidojevic (2017) correctly outline that it would be premature to assume that the low-risk anomaly has been resolved already. This raises the question whether basing the five-factor model on the CAPM has been the right decision. In their article, Blitz et al (2018) even go so far as to suggest that CAPM should not be the basis for any effective asset-pricing model in the first place. Blitz et al. (2018, p 73) further state that an '[...] asset pricing model should be able to explain the existence of an equity risk premium, but also allow for the absence of a return premium to market beta exposure in the cross section [...]'. However, the available postulated asset pricing model should look like if it were not based on the rather dated CAPM.

In addition to the criticism above, another major point of critique about this model is the fact that Fama and French (2015a) have not included momentum as part of the extension of the threefactor model. This is rather confusing as the 
momentum anomaly was already well known and deeply researched by the time of the introduction of the five-factor model in 2015. Even Fama and French (2015a) themselves acknowledged that their model does not capture momentum in a meaningful way, but do not provide further rationale as to why they have decided to omit this factor from their model. Blitz et al. (2018) add to this surprising point that evidence for the momentum premium's equality to size and value was already available in 1993 during the introduction of Fama and French's (2015a) threefactor model. In the referenced study, Jegadeesh and Titman (1993) determined that the described strategies realized significant abnormal returns in the examined period that could not be explained by a systematic risk-based approach. However, Blitz et al. (2018) analyse that this factor was most likely not included as the three-factor model was already finalized when the momentum anomaly was discovered. Somewhat unexpectedly, nevertheless, Fama and French (2008) acknowledged that momentum became a pervasive factor in asset pricing and acknowledge that it cannot be explained with both the CAPM and the three-factor model. One fails to understand why this factor was not added to their five-factor model then, as the inclusion of this factor would have been an incredible leap towards the provision of a truly comprehensive asset pricing model.

An additional issue with this model is the unclear economic rationale that has led to its introduction. As Blitz et al (2018) state, Fama and French have interpreted the SMB and HML factors as priced risk factors that relate to the risk of financial distress. Surprisingly, Fama and French have not provided direct risk-based explanations following the introduction of the RMW and CMA factors. Fama and French (2015a) directly argued during the introduction of the five-factor model that these factors are based on a rewritten version of the dividends discounted model (DDM). As Blitz et al (2018) add, the factors in this model directly imply expected returns in combination with the book-to-market ratio $(\mathrm{B} / \mathrm{M})$. Unfortunately, it is unclear in the literature at this point what the source of these additional factors really is in contrast to CAPM's and the three-factor model's risk foundation. Blitz et al. (2018) complete this point stating that the risk-based explanation of the model has apparently been pushed into the background and that it is therefore not clear what the economic basis for this model really is. At this point, it can only be questioned whether Fama and French (2003) wished to introduce a new fundament for the way asset pricing is being conducted and attempted to move away from the heavily CAPMinfluenced nature of their initial three-factor model. These points, however, are highly speculative and subject to extensive research that will most certainly continue for the near future before conclusive statements can be made. Taking all of these points into consideration, one can see that the Fama and French (2015a) five-factor model appears to be a significant development in the field of asset pricing models, but bears significant flaws which have not been researched sufficiently as of today. Musaruwa (2019) adds to this discussion that the model left significant room for the development of superior asset pricing models and that '[...] it would be in the best interest for investors to use the currently available factor asset-pricing models until the five-factor model has sufficiently been proven in the empirical evidence.' Therefore, this study does not recommend using this model to research the stipulated hypothesis, but will perform calculations based on the Fama French threefactor model that has widely been accepted as a standard in asset pricing by researchers on a global scale.

It should be mentioned at this point that several other factor models have been introduced already which attempt to provide results that are more accurate and eradicate the flaws of the models discussed above. For example, Roy and Shijin (2018) have proposed a six-factor model based on the Fama French five-factor model. Rahman and Schneider (2019) have introduced both augmented versions of the four-factor model. However, these models have not been tested in such an extensive way that it would be possible to draw safe conclusions about their applicability or robustness. At best, they constitute the academic attempt to overcome the shortcomings of the past asset pricing models, but they cannot be considered valid enough yet to replace any of the previously used asset pricing models. Consequently, investors who wish to use such models are primarily left with deciding for a tradeoff. They either have to choose a model that is simple and can be applied easily, like the CAPM, but is practically invalid in most of its applications or go for a more complex, sophisticated option like the Fama French factor models as they have been researched extensively 
with empirical evidence for their validity as well as clearly defined criticism on the limitations of their applicability. Either way, investors must keep in mind that all of these models are only approximations of reality and are, at least as of today, unable to fully explain all factors which affect asset pricing. Consequentially, one must remember that these models are built on sometimes absurd - assumptions to simplify the real-world market behaviour. However, their results can provide meaningful insight into the underlying asset, which may then be tested further for reliability and usage in decisions on investments, comparison of performance of assets or asset classes and the like. One must only note that their results should not be taken as absolutistic truth and that a certain scepticism as well as consciousness about their underlying assumptions are required while applying these models to available data.

\section{Research design}

\subsection{Model for explanation of stock returns}

As mentioned above, this study will rely on the Fama French three-factor model to calculate the cost of equity from the chosen market data. The related regression equation is listed below:

$$
R_{i, t}-R F_{t}=a_{i}+b_{i}\left[R M_{t}-R F_{t}\right]+s_{i} S M B_{t}+h_{i} H M L_{t}+e_{i, t}
$$

In the regression equation, $R_{i, t}$ is the return of the portfolio I for month t, $R F_{t}$ is the risk-free rate, $R M_{t}$ is the market return, $S M B_{t}$ is the difference between returns on diversified portfolios of small and big stocks, $H M L_{t}$ is the difference between the returns on diversified portfolios of high and low $\mathrm{B} / \mathrm{M}$ stocks, and $e_{i, t}$ denotes the error term of portfolio I for month $t$. The cost of equity calculations will be divided into the following subsections to allow the creation of a benchmark and analysis of several periods in time:

- Full Data Period

- During COVID-19 Pandemic Months

- Between GFC and COVID-19

- During GFC

- Before GFC

\subsection{Test of model performance}

As suggested by Gibbons, Ross, and Shanken (1989), the GRS F-test statistic will be applied to evaluate the chosen model's performance on given datasets by testing the null $\mathrm{H}_{0}: \alpha_{\mathrm{i}}=0$ for all of I or simply put, to test the intercepts jointly. The test statistic's calculation is outlined by the following equation:

$$
G R S=\left(\frac{T}{N}\right)\left(\frac{T-N-L}{T-L-1}\right)\left[\frac{\hat{a}, \Sigma^{-1} \hat{a}}{1+\bar{\mu} / \widehat{\Omega}^{-1} \bar{\mu}}\right]
$$

with $\mathrm{T}$ being the sample size, $\mathrm{N}$ displaying the number of portfolios to be explained, $\mathrm{L}$ being the number of explanatory factors, â being a vector of regression intercepts, $\widehat{\Sigma}$ constituting an unbiased estimate of the residual covariance matrix in the sample, and $\widehat{\Omega}$ denoting an unbiased estimate of the factor portfolios' covariance matrix. Following the $\mathrm{H}_{0}$ that all regression intercepts equal zero, the GRS statistic expresses an $\mathrm{F}$ distribution with $\mathrm{N}$ and $\mathrm{T}-\mathrm{N}-\mathrm{L}$ degrees of freedom. Cakici, Fabozzi, and Tan (2013, p 48) add to these points that the application of this test requires the strong assumption that errors in the test are 'independent, identically distributed, and follow the normal law'. Applying this model will allow insights on the ability of the model to explain the variation of returns for a given portfolio. A high value indicates in this case that the value of the combined intercepts is considerably deviating from zero. Therefore, the factors of the models are not effectively explaining the portfolio's return variation, meaning that large values are not desired as an outcome. Consequently, a larger value of the GRS statistic constitutes a larger joint value of the alpha that stray farther from zero then and display an insufficient performance of the asset-pricing model.

\section{Data}

This study will use monthly stock level data from 4 major indices of developed markets (Nasdaq Composite - US, Nikkei 225 - Japan, Dax-30 Germany, and FTSE-100 - United Kingdom) and 4 economically powerful emerging countries (IBOVESPA - Brazil, Shanghai Composite China, Mexico IPC - Mexico, and MOEX Russia) from Yahoo Finance as a basis for the calculation of the cost of equity for companies in these markets. The dataset ranges from January 2000 to the end of August 2020 with an exception for Russia where country-level data was only available from the beginning of October 2000 . Additionally, return data on exemplary companies for two emerging markets and two developed markets will be used to calculate the rate of return for investors looking to invest in companies in 
these specific regions. The used company data will come from Walmart and Apple for the US, SAP and Daimler AG from Germany, China Mobile and SAIC Motor for China, as well as Lukoil and Gazprom for Russia. As a support to these datasets, stock index movements have been researched to determine comparable patterns in their development that may support the notion that emerging markets express a similar reaction to severe economic crises as developed markets. Additionally, the visualized movement data allows a comparison of the crisis recovery potential of the researched countries. The movement data has been restricted between January 2007 and June 2010 for the GFC as well as January 2020 to August 2020 for the COVID19 pandemic to allow a meaningful comparison. Other sources distinguish between the GFC from 2007 to 2008 and the Global Recession between 2008 and 2010. However, for a facilitated reading, this study will singularly refer to this period as GFC. All dataset returns were converted in U.S. dollars; excess returns have been calculated relative to the one-month U.S. Treasury bill rate. A cut-off has been made for data before January 2000 and after August 2020. This approach is in line with French (2017) stating that most investors even look at only four years of data and not several decades of data, which sometimes ranges back to the early $20^{\text {th }}$ century in other sources. Such bigger datasets are usually employed to test the validity of asset pricing models in general, but do not necessarily provide useful decision tools to investors in a real-world setting. This particular time window was chosen to cover 20 years of financial return data that includes large financial crises, especially the GFC and its ensuing Global Recession. This allows an assessment of return data before the GFC, during the GFC, and after the GFC and a comparison with the available return data from the COVID-19 pandemic. No data has been included after August 2020 as the case numbers of COVID-19 were improving following governmental measures that were directed at reducing numbers of infected individuals in each country. Consequently, the researched period was restricted to those months where COVID-19 infection activity has had the most severe effects. It must be mentioned that the COVID-19 pandemic is still ongoing when this study has been prepared. Further governmental restrictions, increasing case numbers and negative economic effects cannot be ruled out at the current time and may have significantly altering effects on the results that are presented below. Therefore, additional data will be available in the future that should be incorporated in additional analyses of these markets.

\subsection{Implementation of asset pricing factors}

This study considers three factors that will be used as explanatory variables in the asset pricing regression given in Equation (1). These factors are the market factor, the SMB factor, and the HML factor. The respective factor data for both developed and emerging markets has been sourced from Kenneth French's factor modelspecific data library, which can be accessed at French, (2020a).

The developed market factors include information from 23 developed countries. The emerging market factors include data from 26 emerging countries. The exact calculation of the factors will not be explained as part of this study as the factor data is being provided and used in a finalized format based on compounded portfolios for a predefined set of developed and emerging countries. Further explanations as to how the factors were obtained can be found in Kenneth French's data library at the following locations for both developed and emerging markets: French, (2020b, 2020c).

It must be noted here that the factor data set for emerging markets also includes additional factors from the five-factor model, namely the profitability and investment factors. The respective data has not been taken into consideration for further calculations due to this study's focus on the three-factor model. An omission of these two factors does not have an impact on the results of the Fama French threefactor model.

\section{Results}

In this section, the empirical results are presented.

\subsection{Stock index movement similarities}

As a benchmark for their performance, the stock indices of both the exemplary emerging and developed countries have been researched to determine how the index value changed during the GFC between 2007 and 2010. Figure 1 outlines the movement overview for all developed market stock indices over the whole sample duration, showing that they react similarly to the researched crises. 


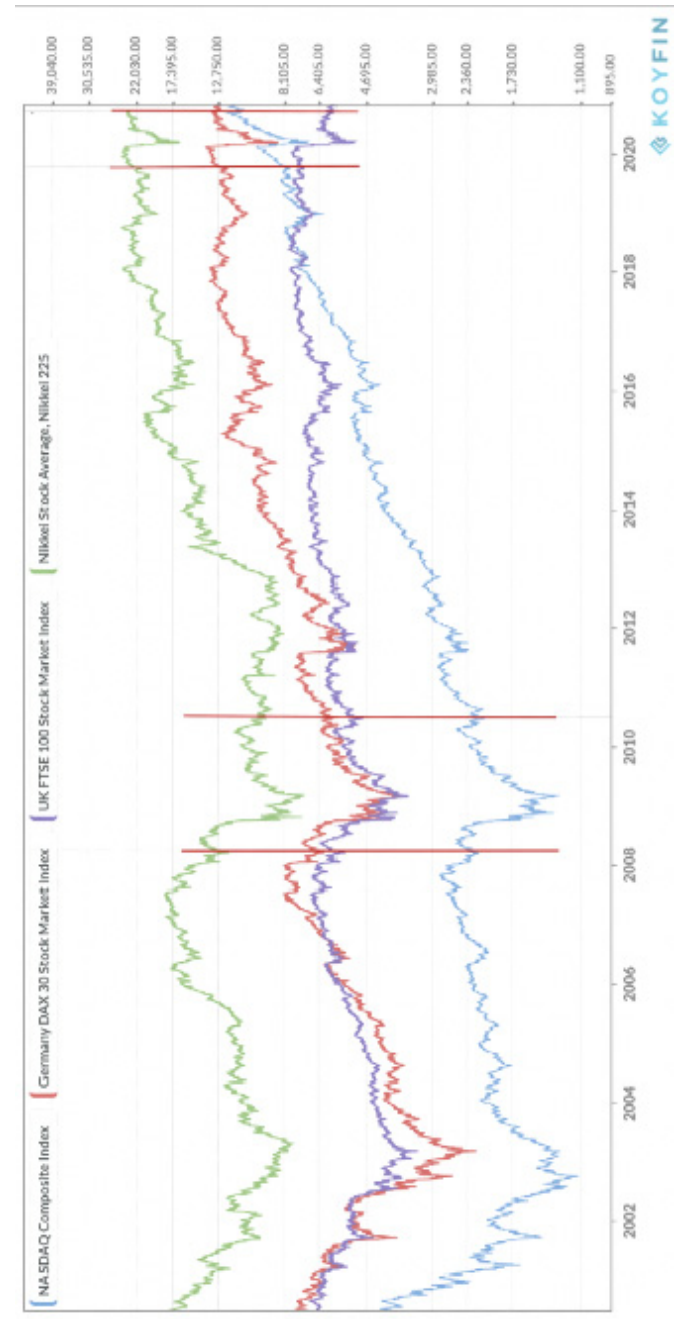

Figure 1 Composite Developed Market Index Overview Global Financial Crisis and COVID-19 Pandemic Source: Koyfin, 2020a, 2020b

On average, the index values for the developed markets dropped by approximately $49 \%$ and increased by roughly $51 \%$ again during the Global Financial Crisis. Similarly, the average decline in the emerging markets ranged at roughly $48 \%$. In contrast, however, the value of the emerging market indices increased, on average, by approximately $99 \%$.

Figure 2 outlines the movement overview for all emerging market stock indices over the whole sample duration, showing that they also react similar to the researched crises as the developed markets.

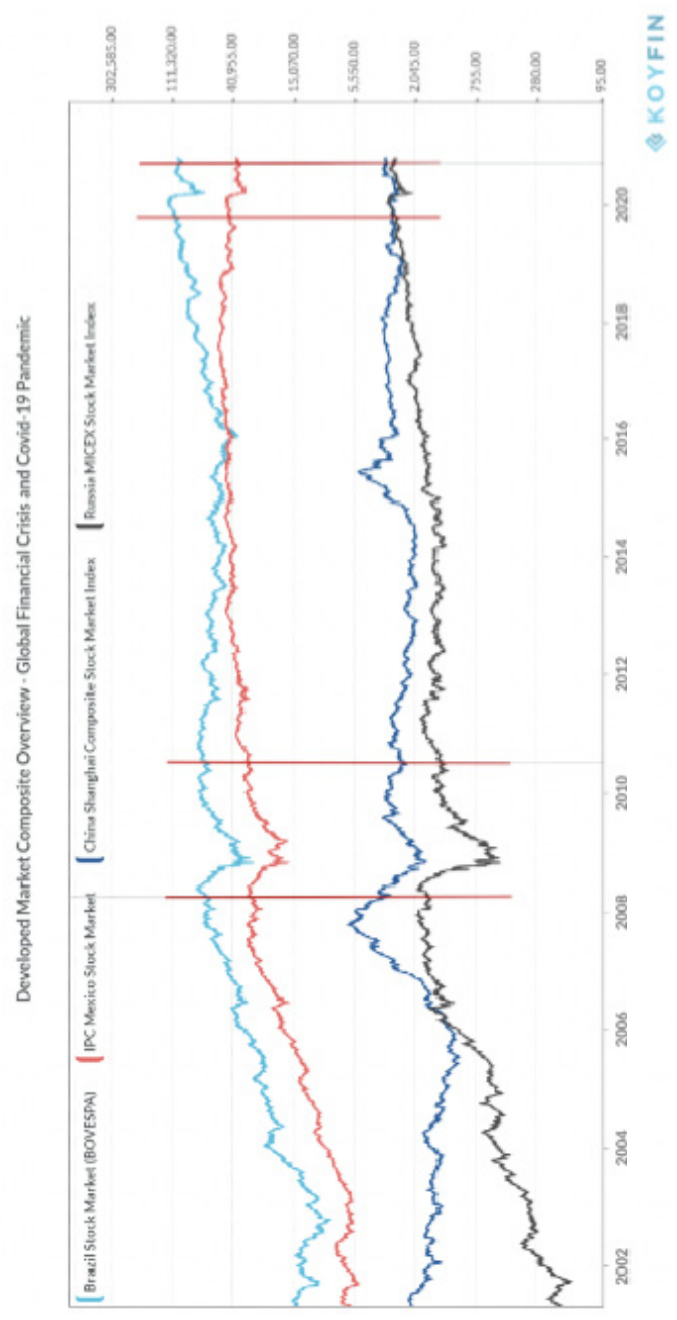

Figure 2 Composite Emerging Market Index Overview Global Financial Crisis and COVID-19 Pandemic Source: Koyfin, 2020a, 2020b

On average, the index values for the developed markets dropped by approximately $35 \%$ and increased by roughly $46 \%$ again during the COVID-19 pandemic, as of now. Similarly, the average decline in the emerging markets ranged at roughly $31 \%$. In contrast, the value of the emerging market indices only increased, on average, by approximately $34 \%$, as of now.

\subsection{Exemplary companies in emerging and developed countries - GFC and Covid-19 pandemic}

As a benchmark for their performance, the stock indices of both the exemplary companies from developed and emerging markets have been researched to determine how their stock value changed during the GFC between 2007 and 2010. On average, the stock values for the exemplary companies from developed markets dropped by 
approximately $32 \%$ and increased by roughly $114 \%$ again during the GFC. Similarly, the average decline in the exemplary companies from emerging markets ranged at roughly $53 \%$. In contrast, however, the value of the emerging market companies increased, on average, by approximately $72 \%$. In comparison, the company stock development for the COVID-19 pandemic period can be found below. On average, the stock values for the exemplary companies from developed markets dropped by approximately $31 \%$ and increased by roughly $90 \%$ again during the past months of the COVID-19 pandemic. Quite similarly, the average decline in the exemplary companies from emerging markets ranged at roughly $39 \%$. In contrast, however, the value of the emerging market companies only increased, on average, by a disappointing $27 \%$.

A composite stock value index visualization has been omitted for the company data as their respective development curves were so close to each other in value that the readability of the graph was significantly reduced. Nevertheless, the data showed that the exemplary companies also reacted in similar patterns to both the GFC and the COVID-19 pandemic.

The values above allow a first indication as to whether emerging markets perform better than developed markets in crises such as the COVID19 pandemic. Both market regions suffered comparable loss levels, both during the GFC and the COVID-19 pandemic. While the emerging markets recovered much better during the GFC with an average recovery of market index value of $99 \%$ compared to $51 \%$ in the developed markets, the emerging markets show a noticeably worse index value recovery of roughly $34 \%$ during the COVID- 19 pandemic, compared to nearly $46 \%$ in the developed market index values.

On an individual company level, the assumed superiority of emerging markets is questioned further by comparing the performance of companies that are based in developed countries compared to those companies that are headquartered in emerging markets. In this case, the companies in developed markets showed less severe value reduction levels of around $32 \%$ compared to the emerging market companies' $53 \%$ during the GFC and slightly less severe reduction levels of nearly $31 \%$ compared to the emerging market companies' 39\% during the COVID-19 pandemic. Remarkably, the value recovery in companies from developed markets was far superior to for those companies that are based in emerging markets. The developed market companies increased their stock value, on average, by $114 \%$ compared to $72 \%$ in the emerging market companies during the GFC. During the COVID-19 pandemic, this finding becomes even more prominent as the developed market companies were able to increase their value, on average, by roughly $90 \%$ again, while the emerging market companies' stock value averagely increased by a mere $27 \%$.

\subsection{Results for stock market index data - emerging and developed countries}

Further results from the application of the Fama French (2015a) three-factor model on both the index and company-level data for the developed and emerging markets will be presented in this section. As already performed above, the results of the exemplary developed and emerging market indices will be presented and compared at this point.

Table 1 Fama French Three-Factor Regressions for Country Indices - Developed and Emerging

\begin{tabular}{|c|c|c|c|c|c|c|}
\hline $\begin{array}{l}\text { Country } \\
\text { Data }\end{array}$ & $a$ & $t(\alpha)$ & $\beta$ & $\mathbf{s}$ & $\mathrm{h}$ & $\begin{array}{l}R^{2} \\
\text { (adjust } \\
\text { ed) } \\
\end{array}$ \\
\hline US & $\begin{array}{l}0,00303 \\
17\end{array}$ & $\begin{array}{l}1,7 \\
1\end{array}$ & 1,10 & 0,36 & $\begin{array}{l}- \\
0,8 \\
8\end{array}$ & 0,82 \\
\hline UK & $\begin{array}{l}- \\
0,00371 \\
46\end{array}$ & $\begin{array}{l}- \\
2,7 \\
0\end{array}$ & 0,74 & $-0,21$ & $\begin{array}{l}0,0 \\
9\end{array}$ & 0,70 \\
\hline Japan & $\begin{array}{l}- \\
0,00308 \\
33\end{array}$ & $\begin{array}{l}- \\
1,2 \\
6\end{array}$ & 0,85 & 0,46 & $\begin{array}{l}0,0 \\
8\end{array}$ & 0,53 \\
\hline $\begin{array}{l}\text { German } \\
y\end{array}$ & $\begin{array}{l}- \\
0,00057 \\
42\end{array}$ & $\begin{array}{l}- \\
0,2 \\
5\end{array}$ & 1,06 & $-0,13$ & $\begin{array}{l}- \\
0,1 \\
3\end{array}$ & 0,64 \\
\hline Russia & $\begin{array}{l}0,01026 \\
02 \\
\end{array}$ & $\begin{array}{l}1,9 \\
5 \\
\end{array}$ & 0,19 & 1,32 & $\begin{array}{l}0,3 \\
9 \\
\end{array}$ & 0,08 \\
\hline China & $\begin{array}{l}0,00025 \\
03\end{array}$ & $\begin{array}{l}0,0 \\
6\end{array}$ & 0,53 & 0,34 & $\begin{array}{l}0,2 \\
5\end{array}$ & 0,18 \\
\hline Brazil & $\begin{array}{l}0,00075 \\
33 \\
\end{array}$ & $\begin{array}{l}0,2 \\
7 \\
\end{array}$ & 0,86 & $-0,70$ & $\begin{array}{l}0,4 \\
2 \\
\end{array}$ & 0,65 \\
\hline Mexico & $\begin{array}{l}0,00414 \\
97\end{array}$ & $\begin{array}{l}1,7 \\
3\end{array}$ & 0,62 & $-0,15$ & $\begin{array}{l}- \\
0,1 \\
3\end{array}$ & 0,53 \\
\hline $\begin{array}{l}\text { GRS } \\
\text { Develop } \\
\text { ed: }\end{array}$ & $\begin{array}{l}14,297,0 \\
99\end{array}$ & & $\begin{array}{l}\text { MAV } \\
\text { A: }\end{array}$ & $\begin{array}{l}0,002 \\
31\end{array}$ & & \\
\hline $\begin{array}{l}\text { GRS } p- \\
\text { value: }\end{array}$ & $\begin{array}{l}2.37 \mathrm{E}- \\
08\end{array}$ & & & & & \\
\hline $\begin{array}{l}\text { GRS } \\
\text { Emergin } \\
\text { g: }\end{array}$ & $\begin{array}{l}7,554,00 \\
4\end{array}$ & & $\begin{array}{l}\text { MAV } \\
\text { A: }\end{array}$ & $\begin{array}{l}0,003 \\
35\end{array}$ & & \\
\hline $\begin{array}{l}\text { GRS } p- \\
\text { value: }\end{array}$ & $\begin{array}{l}5.39 \mathrm{E}- \\
03 \\
\end{array}$ & & & & & \\
\hline $\begin{array}{l}\text { Average } \\
R^{2} \mathrm{DEV}\end{array}$ & $\begin{array}{l}0,67230 \\
2\end{array}$ & & & & & \\
\hline $\begin{array}{l}\text { Average } \\
R^{2} E M \\
\end{array}$ & $\begin{array}{l}0,36110 \\
0\end{array}$ & & & & & \\
\hline
\end{tabular}


While using asset-pricing models, mutual agreement exists in the literature that a model can be considered valid if its intercept value is as close to zero as possible. Fama and French (2004) underline this point, stating that a model only holds its results if there is no possible way to group assets into portfolios in such a way that their intercepts are noticeably different from zero. Consequently, those models that return alphas closest to zero are also the ideal models in explaining asset returns. As shown in table 1, the Fama French three-factor model is successful in producing alpha values that are practically zero for all market indices of both the developed and emerging countries. This is also supported by the multi-attribute value analysis (MAVA) values for both the developed and emerging market indices that are also both practically zero. Three out of the eight alphas showed a negative value, while the remaining five alphas showed a positive value. Surprisingly, only the alpha value for the UK has been statistically significant at the 0.05 significance level. Additionally, the model expresses reasonably acceptable $\mathrm{R}^{2}$ values for the developed markets, with an average $\mathrm{R}^{2}$ of 0.67 and a rather disappointing average $\mathrm{R}^{2}$ of 0.36 for the emerging markets, indicating that other factors must exist in the emerging markets that are able to explain the variation in the dependent variable, but are not captured in the model. However, it must be mentioned as well that this average value is particularly small due to the strikingly low $\mathrm{R}^{2}$ values for Russia and China, while Brazil and Mexico show reasonably high $\mathrm{R}^{2}$ values. All beta values came back as statistically significant at the 0.05 significance level. Five out of eight $\mathrm{s}$ values were reported as statistically significant at the 0.05 significance level and only two out of eight $h$ values were considered statistically significant at the 0.05 significant level. When looking at the GRS statistic values for both the developed and emerging markets, the use of the model is clearly rejected, indicated by GRS statistic values of 14.297 for the developed markets and 7.554 for the emerging markets. The p-values for both GRS test series are close to zero and below the 0.05 significance level, which would indicate that $\mathrm{H}_{0}: \alpha$ $=0$ for all $\mathrm{i}$ of the used Fama French (2015a) three-factor model can be rejected.

The cost of equity, from an investor's perspective, displays the required return for investments in equity, e.g. buying stocks. Consequently, a comparison can be made between the cost of equity of stocks of different regions to assess what kind of returns can be expected in certain areas during specific timeframes. Investors are able to see directly via the cost of equity what kind of returns they can expect in such markets and what level of risk they would need to face to reach these respective values. Average values have been calculated for a facilitated assessment.

Table 2 Fama French Three Factor Model - Cost of Equity Calculation Results Developed and Emerging Countries

\begin{tabular}{l|l|l|l|l|l}
\hline $\begin{array}{l}\text { Country } \\
\text { Data }\end{array}$ & $\begin{array}{l}\text { Full } \\
\text { Period }\end{array}$ & $\begin{array}{l}\text { Covid-19 } \\
\text { Period }\end{array}$ & $\begin{array}{l}\text { Betwee } \\
\text { n GFC } \\
\text { and } \\
\text { Covid- } \\
19\end{array}$ & $\begin{array}{l}\text { During } \\
\text { GFC }\end{array}$ & $\begin{array}{l}\text { Up to } \\
\text { GFC }\end{array}$ \\
\hline US & $3,77 \%$ & $18,91 \%$ & $12,08 \%$ & $-4,39 \%$ & $-14,64 \%$ \\
\hline UK & $5,36 \%$ & $-1,80 \%$ & $8,07 \%$ & $-3,24 \%$ & $3,11 \%$ \\
\hline Japan & $6,49 \%$ & $22,13 \%$ & $7,23 \%$ & $-3,38 \%$ & $8,71 \%$ \\
\hline Germany & $6,45 \%$ & $-17,05 \%$ & $11,72 \%$ & $-4,77 \%$ & $1,84 \%$ \\
\hline Russia & $5,60 \%$ & $146,44 \%$ & $0,30 \%$ & $5,16 \%$ & $6,97 \%$ \\
\hline China & $7,41 \%$ & $-15,39 \%$ & $4,52 \%$ & $9,08 \%$ & $6,72 \%$ \\
\hline Brazil & $11,38 \%$ & $185,19 \%$ & $7,77 \%$ & $7,75 \%$ & $14,15 \%$ \\
\hline Mexico & $5,55 \%$ & $35,71 \%$ & $3,18 \%$ & $9,92 \%$ & $4,86 \%$ \\
\hline $\begin{array}{l}\text { Average } \\
\text { Developed }\end{array}$ & $5,52 \%$ & $5,55 \%$ & $9,78 \%$ & $-3,95 \%$ & $-0,25 \%$ \\
\hline $\begin{array}{l}\text { Average } \\
\text { Emerging }\end{array}$ & $7,49 \%$ & $87,99 \%$ & $3,94 \%$ & $7,98 \%$ & $8,18 \%$ \\
\hline $\begin{array}{l}\text { \% Change } \\
\text { Average } \\
\text { DEV - EM }\end{array}$ & $35,66 \%$ & $1486,07 \%$ & $59,67 \%$ & $302,22 \%$ & $3436,73 \%$ \\
\hline & & & & \\
\hline & & & & & \\
\hline
\end{tabular}

Source: The Authors

For the developed countries, the average cost of equity came back as $-0.25 \%$ before the GFC. For the emerging countries, the average cost of equity ranged around $7.98 \%$ before the GFC. During the GFC, the developed country market indices showed an average cost of equity of $3.95 \%$. The average value of the cost of equity rose to $9.78 \%$ in the developed markets, while the average value for the emerging markets dropped to $3.94 \%$. This finding is in line with Griffin, et al. (2010) who stated that emerging markets might show improved economic recovery rates after crises. Consequently, the reduced cost of equity falls in line with this finding as it indicates that the emerging markets stabilized faster and were able to generate reliable returns from economic activity at a faster rate and with reduced risk than developed markets. Surprisingly, the average cost of equity during the COVID-19 months ranged at 
$5.55 \%$ for the developed country markets. In contrast, the average value for the emerging markets was $87.99 \%$ in that period. As these subperiods only allowed quite narrow data analysis, the full period has been assessed for the calculation of the cost of equity to factor the GFC benchmark values into the calculation as well as the effects during the COVID-19 months. Additionally, the full period was used as a basis for the cost of equity assessment as the use of the whole dataset alleviates the distorting effect of extensive arrays of negative return values in the sub-periods; especially in the GFC and the COVID-19 pandemic which both expressed detrimental repercussions on the performance of markets and thereby created predominantly negative values for all researched markets. The average cost of equity for the developed markets lay at $5.52 \%$, while the emerging markets showed a cost of equity of $7.49 \%$. No data is available for a calculation of an additional subset after the COVID-19 pandemic, simply because the pandemic is not over yet. At this point, one may deduct that the developed markets performed slightly better than the emerging markets, as the emerging markets express a total cost of equity, which is roughly $35.66 \%$ above the calculated cost of equity of the developed markets. The full period calculation shows a contrasting picture to the findings of Griffin et al. (2010), namely that the economic performance and rate of crisis recovery becomes worse in the emerging countries as soon as the COVID-19 pandemic period is included in the calculation. Nevertheless, it is not possible to estimate the further effects of the COVID-19 pandemic on the cost of equity for these markets as the pandemic is still ongoing and the affected countries have not been able to recover fully from its effects at all at the current moment.

\subsection{Results for company stock data - emerging and developed countries}

As shown in Table 3, the Fama French (2015a) three-factor model is also successful in producing alpha values, which are close to zero for all exemplary company-level stock data of both the developed and emerging markets.
Table 3 Fama French Three Factor Regressions for

Company Stock Data - Developed and Emerging

\begin{tabular}{|c|c|c|c|c|c|c|}
\hline $\begin{array}{l}\text { Company } \\
\text { Data }\end{array}$ & $\alpha$ & $\mathrm{t}(\mathrm{a})$ & $\beta$ & 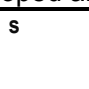 & $\mathrm{h}$ & $\begin{array}{l}R^{2} \\
\text { (adjus- } \\
\text { ted) }\end{array}$ \\
\hline Apple & 0,0237875 & 3,88 & 1,25 & 0,19 & $\overline{1,11}$ & 0,33 \\
\hline $\begin{array}{l}\text { Wal } \\
\text { mart }\end{array}$ & 0,0043526 & 1,38 & 0,34 & $-1,15$ & $\overline{0}, 16$ & 0,20 \\
\hline $\begin{array}{l}\text { Daimler } \\
\text { AG }\end{array}$ & $-0,0023196$ & $\overline{0}, 50$ & 1,46 & 0,28 & 0,20 & 0,46 \\
\hline SAP & 0,0067615 & 1,27 & 1,17 & $-0,34$ & $\overline{0}, 96$ & 0,34 \\
\hline Lukoil & 0,0049115 & 0,90 & 1,04 & $-0,37$ & 0,46 & 0,39 \\
\hline Gaz-prom & 0,0028662 & 0,36 & 0,84 & 1,31 & 0,73 & 0,17 \\
\hline $\begin{array}{l}\text { SAIC } \\
\text { Motor }\end{array}$ & 0,0075910 & 1,04 & 0,58 & 0,14 & 0,68 & 0,11 \\
\hline $\begin{array}{l}\text { China } \\
\text { Mobile }\end{array}$ & 0,0060114 & 1,36 & 0,67 & $-1,20$ & 0,96 & 0,37 \\
\hline $\begin{array}{l}\text { GRS } \\
\text { Deve- } \\
\text { loped: }\end{array}$ & 20,476466 & & MAVA: & 0,007821 & & \\
\hline $\begin{array}{l}\text { GRS } p- \\
\text { value: }\end{array}$ & $3,331 \mathrm{E}-16$ & & & & & \\
\hline $\begin{array}{l}\text { GRS } \\
\text { Eme- } \\
\text { rging: }\end{array}$ & 4,1728705 & & MAVA: & 0,001456 & & \\
\hline $\begin{array}{l}\text { GRS } p- \\
\text { value: }\end{array}$ & 0.00234312 & & & & & \\
\hline $\begin{array}{l}\text { Ave-rage } \\
R^{2} \mathrm{DEV}\end{array}$ & 0,331614 & & & & & \\
\hline $\begin{array}{l}\text { Ave-rage } \\
R^{2} E M\end{array}$ & 0,257887 & & & & & \\
\hline
\end{tabular}

This is also supported by the MAVA values for each company sets, which are both practically zero. One out of the eight alphas showed a negative value with no further negative alpha values being present in the data set. Surprisingly, only the alpha value for Apple has been statistically significant at the 0.05 significance level. Additionally, similarly to the market index results, the model expresses dissatisfying $\mathrm{R}^{2}$ values; this time for both the developed and emerging markets, with even worse values for $\mathrm{R}^{2}$. An average $\mathrm{R}^{2}$ of 0.33 has been received for the companies in developed markets and an average $\mathrm{R}^{2}$ of 0.25 for the emerging markets, also strongly indicating that other factors must exist in the markets that are able to explain the variation in the dependent variable, but are not captured in the model. All beta values came back as statistically significant at the 0.05 significance level. Only three out of eight $s$ values were reported as statistically significant at the 0.05 significance level, but four out of eight $h$ values were considered statistically significant at the 0.05 significant level. When looking at the GRS statistic results for both the developed and emerging markets, the use of the model is also strongly rejected, indicated by GRS test values of 
20.4764 for the developed markets and 4.1728 for the emerging markets. Although the GRS value for the emerging market companies is visibly smaller than the GRS value for the emerging markets, the use of the model is still rejected as well. The p-values for the GRS test series of the developed and emerging market companies are also close to zero, which indicates that $\mathrm{H}_{0}: \alpha=0$ for all i of the used Fama French (2015a) three factor model can be rejected for the developed and emerging market companies.

Similar to the market indices, the cost of equity was also calculated for the exemplary companies in developed and emerging markets.

Table 4 Fama French Three Factor Model - Cost of Equity Calculation Results Exemplary Companies - Developed and

\begin{tabular}{l|l|l|l|l|l}
\multicolumn{6}{c}{ Emerging Markets } \\
\hline $\begin{array}{l}\text { Company } \\
\text { Data }\end{array}$ & $\begin{array}{c}\text { Full } \\
\text { Period }\end{array}$ & $\begin{array}{c}\text { Covid-19 } \\
\text { Period }\end{array}$ & $\begin{array}{c}\text { Between } \\
\text { GFC and } \\
\text { Covid-19 }\end{array}$ & $\begin{array}{c}\text { During } \\
\text { GFC }\end{array}$ & $\begin{array}{c}\text { Up to } \\
\text { GFC }\end{array}$ \\
\hline Apple & $5,02 \%$ & $51,09 \%$ & $14,77 \%$ & $-7,68 \%$ & $-5,95 \%$ \\
\hline Walmart & $1,84 \%$ & $91,35 \%$ & $6,46 \%$ & $-0,91 \%$ & $1,58 \%$ \\
\hline $\begin{array}{l}\text { Daimler } \\
\text { AG }\end{array}$ & $9,75 \%$ & $-47,26 \%$ & $15,50 \%$ & $-6,56 \%$ & $8,46 \%$ \\
\hline SAP & $4,56 \%$ & $-21,86 \%$ & $12,15 \%$ & $-2,14 \%$ & $-15,44 \%$ \\
\hline Lukoil & $12,96 \%$ & $274,48 \%$ & $7,30 \%$ & $6,54 \%$ & $21,87 \%$ \\
\hline Gazprom & $12,79 \%$ & $284,06 \%$ & $3,55 \%$ & $12,11 \%$ & $16,56 \%$ \\
\hline $\begin{array}{l}\text { SAIC } \\
\text { Motor }\end{array}$ & $10,84 \%$ & $-59,76 \%$ & $4,45 \%$ & $22,73 \%$ & $16,92 \%$ \\
\hline $\begin{array}{l}\text { China } \\
\text { Mobile }\end{array}$ & $0,40 \%$ & $-200,33 \%$ & $4,05 \%$ & $-13,82 \%$ & $-15,03 \%$ \\
\hline $\begin{array}{l}\text { Average } \\
\text { Developed }\end{array}$ & $5,29 \%$ & $18,33 \%$ & $12,22 \%$ & $-4,32 \%$ & $-2,84 \%$ \\
\hline $\begin{array}{l}\text { Average } \\
\text { Emerging }\end{array}$ & $9,25 \%$ & $74,61 \%$ & $4,84 \%$ & $6,89 \%$ & $10,08 \%$ \\
\hline $\begin{array}{l}\text { \% Change } \\
\text { Average } \\
\text { DEV - EM }\end{array}$ & $74,73 \%$ & $307,05 \%$ & $60,41 \%$ & $259,40 \%$ & $455,24 \%$ \\
\hline & & & & \\
\hline & & & & & \\
\hline
\end{tabular}

The same sub-periods were assessed. Unsurprisingly, the calculated value patterns are similar for all companies. Nevertheless, the magnitude of the values is different to those observed in the full market datasets. In the period before the GFC, the average cost of equity for the developed market companies was $-2.84 \%$, while the emerging market companies showed average cost of equity values of $10.08 \%$. The average values during the GFC came back as $-4.32 \%$ for the developed market companies and $6.89 \%$ for the emerging market companies. These values are heavily influenced by extensive arrays of negative return data during the GFC and must be taken with caution as these values, as above, indicate severely unfavourable economic effects, which pulled a majority of data points into a negative range. The period between the GFC and the COVID-19 expressed the same value pattern as the market data. The average cost of equity of the companies in developed markets lay at $12.22 \%$, while the cost of equity for companies in the emerging markets was a considerably lower at $4.84 \%$. For the COVID-19 period, the average cost of equity for developed market companies was $18.33 \%$. The average cost of equity for the emerging market companies came back as $74.61 \%$. As with the data for the market indices, the full period has been assessed for the cost of equity of the analysed companies for a more trustworthy result. In this context, the cost of equity for the companies in developed markets was $5.29 \%$, similar to the market indices data. Contrastingly, the cost of equity for the companies in emerging markets returned as $9.25 \%$, which was roughly $74 \%$ higher than the cost of equity for the companies in the developed markets.

\section{Conclusion}

\subsection{Model performance in developed and emerging markets}

It has been shown in tables 1 and 3 that the underlying model for the assessment only partially performed as expected. It is especially surprising to see that the $\mathrm{R}^{2}$ values as an initial measure of model performance differed widely for the employed index and company data with values ranging from $<0.1$ to $>0.8$ for the index data and $<0.2$ to $>0.4$ for the company data. Although there is no strict rule for the classification of goodness of fit of the model for this value, Zikmund (2013) provides a rule of thumb for the classification of these results:
- $\mathrm{r}<0.3$ effect

- $0.5<\mathrm{r}<0.7$

- $\mathrm{r}>0.7$
- $0.3<\mathrm{r}<0.5$ no or very weak size weak size effect moderate size effect strong size effect
Keeping this classification in mind, it is intriguing to see in the model's regression results for developed markets that the independent variables only have a strong size effect in two of the researched country indices, namely the US and UK. The values for Japan and Germany merely indicate a moderate size effect. However, these results are satisfying for this setting 
suggested in the article as they indicate that the independent variables in the underlying Fama French (2015a) three-factor model are able to explain at least $53 \%$ to more than $80 \%$ of the variance in the dependent variable and thereby allow a sufficiently meaningful determination of the cost of equity. However, these values are already invalidated to some extent by the GRS statistic results. This value speaks a different language in this regard, indicating that the model is rejected due to its GRS values straying strongly from zero and thereby indicating that the model is considerably unable to explain the variation in returns of the researched indices in developed markets. A less satisfying outcome is received for the emerging market indices which show very weak to only moderate size effects for the independent variables of the three-factor model where $\mathrm{R}^{2}$ values between $<0.1$ and $<0.7$ were received. While the emerging market indices show a GRS statistic which is superior to the developed market indices, its effectiveness in explaining the variation in the returns of the researched emerging market indices is still rejected due to its GRS value being considerably larger than zero. Similar conclusions can be drawn from the comparison of more locally levelled data from the researched companies in the developed and emerging markets. It is surprising to see for these exemplary companies that their $\mathrm{R}^{2}$ values do not reach values $>0.5$. In this case, the independent variables from the model are only able to explain $11 \%$ to $46 \%$ of the variance in the dependent variable. Additionally, the GRS statistic also indicated a poor performance of the model in the exemplary developed market companies where the GRS statistic was approximately $43 \%$ larger than the value for the developed market index data. For the emerging market companies, the GRS statistic was considerably closer to zero than the GRS statistic of the developed market companies. Nevertheless, this value also leads to a rejection of the model's performance, as it is considerably larger than zero. Despite these rejections, the GRS statistic shows a superiority in performance of the Fama French three-factor model in emerging regions due to its lower GRS values for both the market indices and the exemplary companies. Although the values are not close to zero, they are considerably below the values for the developed market data.

\subsection{Choice of equity investment}

Tables 2 and 4 carry a strong and clear message: The emerging markets performed considerably worse than developed markets during the COVID19 pandemic in terms of the cost of equity for investments in these areas. Consequently, the thesis that emerging markets express investment potential at better cost of equity levels than developed markets during the COVID-19 pandemic does not hold true and must be rejected. As the calculations showed, both sample sets market indices and exemplary companies expressed massively higher cost of equity during that period. As for the country indices, the cost of equity for the emerging markets was approximately 15 times higher than the cost of equity for developed markets during that period: $5,55 \%$ in developed markets and $87,99 \%$ in emerging markets. A similar outcome has been observed for the exemplary company data where the cost of equity was roughly three times higher for emerging market companies than for companies in the developed markets; $18,33 \%$ for developed market companies and $74,61 \%$ for emerging market companies. At this point, it is already apparent that investors who are looking for suitable options in similar situations would face a significant challenge. While such numbers constitute a nightmare for risk-averse investors, even an extremely risk-seeking investor would find it hugely difficult to determine a suitable number of equity investment options, which yield returns between $70-80 \%$ in a reasonable timeframe without accepting uncontrollable levels of risk for such investments. These numbers are, however, not as much of a surprise as it may seem. Remember at this point that Didier et al. (2011) found that emerging markets recovered faster from the GFC than the developed markets. However, this superior recovery resulted from structural, organizational, and political differences between emerging and developed markets, which made the emerging markets more resistant to the GFC than the developed markets. The COVID-19 pandemic, however, gives a completely different picture. The very nature of this crisis is a severe disruption of essential aspects of a significant portion of economic sectors. As it compels governments worldwide - regardless of the development state - to restrict population movement, people are increasingly forced to stay at home in order to minimize contact to other people and thereby reducing the risk of spreading or contracting this disease. Consequently, all 
ensuing economic activities are severely affected as well; be it recreational events, travelling, sports, the food service industry, or the provision of practically any service, which requires human interaction. As a substantial number of people faced unemployment because of this crisis, private consumer expenditure decreased which led to a drastically reduced demand for consumer products. As most emerging countries are typically focused on manufacturing products instead of being more service based, these developments had radical effects on the performance of these markets and resident companies. Consequently, these markets are being affected much more severely than the developed markets, compared to the GFC. It remains unclear at the moment if these effects can be remedied in the emerging markets again as during the GFC since the COVID-19 pandemic is far from over at the moment. One may ask at this point now what a good strategy would be in terms of equity investments in a time like this. Looking at the data in tables 2 and 4, it becomes clear that no straightforward answer exists for this question. Although the average cost of equity of emerging markets is clearly higher than in the developed markets, the results also show that all markets were and continue to be affected severely by this crisis. This becomes visible by the negative numbers in each table. Such results, while unexpected, show that the respective markets have experienced severe economic turmoil and are experiencing severe effects of this crisis on their overall return performance as well. The same outcome applies to the exemplary company data where negative values were observed for half of the analysed companies in both datasets. In addition, those results that came back positive are not exactly stunning as well.

In order to provide a meaningful recommendation, one additional, critical component will need to be taken into consideration at this point: irrational behaviour due to cognitive bias in investors. The analyses above - just like the underlying asset pricing models - are based on the assumption of rational investor behaviour. Garcia (2011) adds to this point that investors collect and utilize the full range of available information to realize profits and that investors have an endless ability to process new information, which will be used to update their point of view on a continuous basis. However, these assumptions are far from being the truth, as more recent findings in the field of behavioural finance showed (Kareem \& Alameer, 2019). In this field, cognitive biases are analysed, which exist in private and institutional investors alike, affecting them on a broader basis and clouding the rationality of their investment decisions. Bansal (2020) outlines that individuals express a tendency to focus on such information which is easily accessible and absorb information at face value as this crisis continues. Bansal (2020) directly attributes this claim to the primary cognitive issues in behavioural finance:

- Representation bias

- Overconfidence

- Risk aversion

- Herding behavior

- Availability bias

For this study, the representation bias and overconfidence issues are critically important in terms of the provision of a clear investment recommendation. As explained by Zhang (2008, cited in Bansal, 2020), representation bias is a state in which individuals tend to associate a situation with equivalents of a similar nature and draw forecasts from this equivalent. Statman (2020, cited in Bansal, 2020) further defines this point by explaining that the current crisis is often compared to the stock market's state around 2009. Here, a reversal of the market decline has been observed, but may potentially be representative of the stock market during any other detrimental crisis where a reversal of the market decline has not been observed before several years have passed. The overconfidence bias is further segmented by Bansal (2020) into sub-categories:

- Miscalibration

- Better-than-average effect

- Illusion of control

- Unrealistic Optimism

All of these categories result in a critical misjudgement in an individual towards investment knowledge, paired with the assumption that their own information is superior to the knowledge of everyone else.

Going back to the calculated results from the data of this thesis, these biases could have a significant effect on the investment recommendation:

- Would investors invest in preferred markets based on information that they simply like instead of gathering the right bits of data for an informed decision? 
- Would they ignore the risk of equity investments, because they think that their judgment and information is superior to that of other investors?

- How would an investor justify an equity investment in a company that is currently severely troubled with no signs of improvement of the current pandemic situation?

As a recommendation to answer such questions, this study suggest the following route of action:

- Critically and realistically assess your acceptable level of risk.

- Carefully select potential markets and companies for investments based on rational criteria, not sentiments towards certain global regions or specific companies.

- Scrutinize the available information once you have selected potential investments and assess where compiling has been done rationally or more on a sentimental basis.

- Potentially consider other investment options with reduced returns, but increased probability of yielding acceptable returns at bearable risk levels if the current equity investments turn out to be too dangerous.

- Do not rush decisions, as the current situation is still unfolding and may change at any time, potentially for the worse with the threat of incurring substantial losses.

While these recommendations are intentionally written in a generalized manner, they may still be used as a meaningful guidance for investors who are looking for potential equity investments in order to carefully assess one's own strategy and rule out the potential for cognitive bias to invest as rational as possible in a situation which presents more than enough room for irrational behaviour.

\section{Limitations and further research}

At the current moment, no valid studies exist which strictly analyse the economic impact of pandemics of the nature of SARS-CoV-2. As mentioned above, this research gap exists because pandemics of such magnitude have never occurred before. Consequently, it is not possible to compare the findings of this work to other research in this direction and integrate them into the existing body of research results. Therefore, this article provides novel insights in this field, which may be used as a basis to conduct further studies on future available data from this pandemic situation. Additionally, as discussed, the calculated results have shown that other factors must exist in addition to the market beta and the Fama French-specific size and value factors to explain the return development of underlying assets during pandemic situations. These limiting findings are in line with the currently existing body of criticism of the Fama French models as well as CAPM-based factor models in general. Further research and asset pricing model developments would be required to determine these factors in order to allow investors to make an informed decision on potential investment options. As pandemics are global events, which cause economic effects on a macroeconomic level, it would potentially be worthwhile to use the Arbitrage Pricing Model as described by Ross (1976) in further studies, which employs a linear relationship between an asset's return and a number of - self-selected macroeconomic factors. While this model is far more complex than the used asset pricing model in this research study, it may provide further insights into the determining factors of asset returns in pandemic situations; however, at the cost of widely increased levels of effort to determine potential factors upfront instead of using the predefined factors in the Fama French three-factor model.sm

\section{References}

Amadeo, K., (2020). Emerging Market Countries and Their Five Defining Characteristics. The Balance. Retrieved December 1, 2020, from

https://www.thebalance.com/what-are-emergingmarkets-3305927

Arnold, G., \& Lewis, D. (2019). Corporate Finance Management. New York: Pearson Education.

Bansal, T. (2020). Behavioral Finance and COVID-19: Cognitive Errors that Determine the Financial Future. SSRN Electronic Journal. https://doi.org/10.2139/ssrn.3595749

Banz, R. W. (1981). The relationship between return and market value of common stocks. Journal of Financial Economics, 9(1), 3-18. https://doi.org/10.1016/0304-405X(81)90018-0

Belyh, A. (2019). The Definitive Guide to Fama-French Three-Factor Model. Cleverism. Retrieved 3 August 2020, from https://www.cleverism.com/fama-frenchthree-factor-model-guide/.

Blitz, D., \& Vidojevic, M. (2017). The profitability of lowvolatility. Journal of Empirical Finance, 43, 33-42. https://doi.org/10.1016/j.jempfin.2017.05.001 
Blitz, D., Hanauer, M. X., Vidojevic, M., \& Vliet, P. van. (2018). Five Concerns with the Five-Factor Model. The Journal of Portfolio Management, 44(4), 71-78. https://doi.org/10.3905/jpm.2018.44.4.071

Cakici, N., Fabozzi, F. J., \& Tan, S. (2013). Size, value, and momentum in emerging market stock returns. Emerging Markets Review, 16, 46-65. https://doi.org/10.1016/..ememar.2013.03.001

Didier, T., Hevier, C., \& Schmukler, S. (2011). The resilience of emerging markets during the global crisis | VOX, CEPR Policy Portal. Voxeu.org. Retrieved 19 September 2020, from https://voxeu.org/article/resilience-emerging-marketsduring-global-crisis.

Drobot, E.V., Makarov, I.N., Nazarenko, V.S., \& Manasyan, S.M. (2020). Влияние пандемии COVID-19 на реальный сектор экономики (Impact of the COVID-19 pandemic on the real economy). Journal of Economics, Entrepreneurship and Law, 10(8), 2135-2150. https://doi.org/10.18334/epp.10.8.110790

Fama, E. F., \& French, K. R. (1993). Common risk factors in the returns on stocks and bonds. Journal of Financial Economics, 33(1), 3-56. https://doi.org/10.1016/0304-405X(93)90023-5

Fama, E. F., \& French, K. R. (1996). Multifactor Explanations of Asset Pricing Anomalies. The Journal of Finance, 51(1), 55-84. https://doi.org/10.1111/j.1540-6261.1996.tb05202.x

Fama, E. F., \& French, K. R. (1998). Value versus Growth: The International Evidence. The Journal of Finance, 53(6), 1975-1999. https://doi.org/10.1111/0022-1082.00080

Fama, E. F., \& French, K. R. (2004). The Capital Asset Pricing Model: Theory and Evidence. Journal of Economic Perspectives, 18(3), 25-46. https://doi.org/10.1257/0895330042162430

Fama, E., \& French, K. (2003). The Capital Asset Pricing Model: Theory and Evidence. Journal Of Economic Perspectives, 18(3), 41-44. https://doi.org/10.1257/0895330042162430

Fama, E. F., \& French, K. R. (2008). Dissecting Anomalies. The Journal of Finance, 63(4), 1653-1678. https://doi.org/10.1111/j.1540-6261.2008.01371.x

Fama, E. F., \& French, K. R. (2015a). A five-factor asset pricing model. Journal of Financial Economics, 116(1), $1-22$. https://doi.org/10.1016/i.jineco.2014.10.010

Fama, E. F., \& French, K. R. (2015b). Dissecting Anomalies with a Five-Factor Model. Review of Financial Studies, 29(1), 69-103. https://doi.org/10.1093/rfs/hhv043

French, J. (2017). Macroeconomic Forces and Arbitrage Pricing Theory. Journal of Comparative Asian Development, 16(1), 1-20. https://doi.org/10.1080/15339114.2017.1297245

French, K. R. (2020a). Current Research Returns. Retrieved December 1, 2020, from http://mba.tuck.dartmouth.edu/pages/faculty/ken.french/ data_library.html

French, K. R. (2020b). Description of Fama/French 3 Factors for Developed Markets. Retrieved December 1, 2020, from http://mba.tuck.dartmouth.edu/pages/faculty/ken.french/ Data_Library/f-f_3developed.html
French, K. R. (2020c). Description of Fama/French 5 Factors for Emerging Markets. Retrieved December 1, 2020, from

http://mba.tuck.dartmouth.edu/pages/faculty/ken.french/ Data_Library/f-f_3developed.html

García, M. J. R. (2011). Financial Education and Behavioral Finance: New Insights into the Role of Information in Financial Decisions. Journal of Economic Surveys, 27(2), 297-315. https://doi.org/10.1111/j.1467-6419.2011.00705.x

Gibbons, M. R., Ross, S. A., \& Shanken, J. (1989). A Test of the Efficiency of a Given Portfolio. Econometrica, 57(5), 1121.

https://doi.org/10.2307/1913625

Graham, J. R., \& Harvey, C. R. (2001). The theory and practice of corporate finance: evidence from the field. Journal of Financial Economics, 60(2-3), 187-243. https://doi.org/10.1016/S0304-405X(01)00044-7

Griffin, J. M., Kelly, P. J., \& Nardari, F. (2010). Do Market Efficiency Measures Yield Correct Inferences? A Comparison of Developed and Emerging Markets. Review of Financial Studies, 23(8), 3225-3277. https://doi.org/10.1093/rfs/hhq044

Jegadeesh, N., \& Titman, S. (1993). Returns to Buying Winners and Selling Losers: Implications for Stock Market Efficiency. The Journal of Finance, 48(1), 6591. https://doi.org/10.1111/j.1540-6261.1993.tb04702.x

Jensen, M., Black, F., \& Scholes, M. (1972). The Capital Asset Pricing Model: Some Empirical Tests. Papers.ssrn.com. Retrieved 10 October 2020, from https://papers.ssrn.com/sol3/papers.cfm?abstract_id=9 08569

Kareem, M. A., \& Alameer, A. A. A. (2019). The Impact of Dynamic Capabilities on Organizational Effectiveness. Management \& Marketing. Challenges for the Knowledge Society, 14(4), 402-418. https://doi.org/10.2478/mmcks-2019-0028

Koyfin. (2020a). Composite Developed Market Index Overview - Global Financial Crisis And COVID-19 Pandemic. Retrieved 24 October 2020, from https://www.koyfin.com/charttemplate/5f81f59ea720a1f 77a47ba2/NASDAQCOM

Koyfin. (2020b). Composite Emerging Market Index Overview - Global Financial Crisis And COVID-19 Pandemic. Retrieved 25 October 2020, from https://www.koyfin.com/charttemplate/5f81f59aea720a1 f77a47ba2/MEXBOL\#

Lintner, J. (1965). The Valuation of Risk Assets and the Selection of Risky Investments in Stock Portfolios and Capital Budgets. The Review of Economics and Statistics, 47(1), 13. https://doi.org/10.2307/1924119

Moerman, G. A. (2005). How Domestic is the Fama and French Three-Factor Model? An Application to the Euro Area. SSRN Electronic Journal. https://doi.org/10.2139/ssrn.738363

Mossin, J. (1966). Equilibrium in a Capital Asset Market. Econometrica, 34(4), 768. https://doi.org/10.2307/1910098

MSCI. (2014). Market_Classification_Framework, Retrieved 14 September 2020 , from https://www.msci.com/documents/1296102/1330218/M SCl_Market_Classification_Framework.pdf/d93e536fcee $\overline{1}-4 \mathrm{e} 12-\overline{9} \mathrm{~b} 69-\mathrm{ec} 3886 \mathrm{ab} 8 \mathrm{cc} 8$. 
Musarurwa, R. (2019). Fama French Five Factor Asset Pricing Model. QuantInsti. Retrieved 14 September 2020, from https://blog.quantinsti.com/fama-french-fivefactor-asset-pricing-model/.

Rahman, S., \& Schneider, M. J. (2019). Tests of Alternative Asset Pricing Models Using Individual Security Returns and a New Multivariate F-Test. Review of Pacific Basin Financial Markets and Policies, 22(01), 1950001. https://doi.org/10.1142/S0219091519500012

Roll, R. (1977). A critique of the asset pricing theory's tests Part I: On past and potential testability of the theory. Journal Of Financial Economics, 4(2), 129-176. https://doi.org/10.1016/0304-405X(77)90009-5

Ross, S. (1976). The arbitrage theory of capital asset pricing. Journal Of Economic Theory, 13(3), 341-360. https://doi.org/10.1016/0022-0531(76)90046-6

Roy, R., \& Shijin, S. (2018). A six-factor asset pricing model. Borsa Istanbul Review, 18(3), 205-217. https://doi.org/10.1016/j.bir.2018.02.001

Sanche, S., Lin, Y. T., Xu, C., Romero-Severson, E., Hengartner, N., \& Ke, R. (2020). High Contagiousness and Rapid Spread of Severe Acute Respiratory Syndrome Coronavirus 2. Emerging Infectious Diseases, 26(7), 1470-1477. https://doi.org/10.3201/eid2607.200282
Sharpe, W. F. (1964). Capital Asset Prices: A Theory of Market Equilibrium under Conditions of Risk. The Journal of Finance, 19(3), 425. https://doi.org/10.2307/2977928

Subic, J., Vasiljevic, Z., \& Andrei, J. (2010). The impact of FDI on the European economic development in the context of diversification of capital flows. Proceedings of the 14th International Business Information Management Association, Business Transformation through Innovation and Knowledge Management: An Academic Perspective, Istanbul, Turkey, 23-24.

O'Sullivan, A and Sheffrin, M., (2003). Economics: Principles in Action. Upper Saddle River, New Jerse: Pearson Prentice Hall.

Vertakova Y., Plotnikov V. (2013). Russian and foreign experience of interaction between government and business. World Applied Sciences Journal, 28, 411415.

Waszczuk, A. (2013). A risk-based explanation of return patterns-Evidence from the Polish stock market. Emerging Markets Review, 15, 186-210. https://doi.org/10.1016/i.ememar.2012.12.002

Zikmund, W. (2013). Business Research Methods. 9th ed. Mason: South-Western, Cengage Learning.

\section{$\triangle$ Correspondence}

\section{Konstantin B. Kostin}

Saint-Petersburg State University of Economics Sadovaya str. 21, office 2094 St. Petersburg 191023, Russia

E-mail: kost_kos@mail.ru 